\title{
Title Patient Involvement in the Encounter between General Practice and Patients with Chronic Diseases - A Scoping Review
}

Signe Beck Titlestad ( $\square$ sibeck@health.sdu.dk)

University of Southern Denmark

Michael Marcussen

University of Southern Denmark

Marie Sandstød Rasmussen

University of Southern Denmark

Birgitte Nørgaard

University of Southern Denmark

\section{Research Article}

Keywords: Scoping Review, Chronic Disease, Patient Involvement, General Practice, COPD, Diabetes type 2, DM2, Patient perspectives

Posted Date: May 13th, 2021

DOl: https://doi.org/10.21203/rs.3.rs-498932/v1

License: @ (i) This work is licensed under a Creative Commons Attribution 4.0 International License. Read Full License 


\section{Abstract}

Background Globally, there is increasing interest in patient involvement in healthcare. Research has shown improved health outcomes when patients are involved in managing their own health conditions and when their individual needs are considered. The aim of this scoping review was to map the existing research regarding chronic disease patients' involvement in their encounters with general practice, with a specific focus on patients with Type 2 diabetes (TD2) or (Chronic obstructive pulmonary disease (COPD).

Methods Studies of any design, date, and language reporting the involvement of adult patients with T2D or COPD were included. A systematic search was conducted using the following databases: MEDLINE, CINAHL, Psycinfo Scopus, and EMBASE. All databases were searched from August 2020 until October 2020. Data were systematically charted by the following study characteristics: Bibliographic aims; study aims; setting; area of interest; results; conclusion.

Results 19 studies were included and published between 2001 and 2020 and conducted qualitative methods, survey, or mixed methods. Three and 17 studies contained knowledge on the involvement of patients with COPD and TD2, respectively. The patients reported the importance of being more involved in treatment discussions during consultations as well as a friendly environment. A good relationship and relational continuity make it easier for patients to be more involved in treatment decisions. The general practitioners(GP) mentioned their high work load, long-standing relationships, knowledge about the patients, and prepared patients as factors influencing their ability to involve patients in treatment discussions.

Conclusion The existing knowledge within patient involvement in general practice clearly indicates that focus and action must be directed towards research exploring the perspectives of patients with COPD on their involvement in general practice.

\section{Background}

Globally, there is an increasing interest in patient involvement in healthcare $(1,2)$. Research demonstrates improved health outcomes when patients are involved in the management of their own health conditions and when their individual needs are taken into account $(3,4)$. Furthermore, the positive influence of patient involvement in relation to treatment and well-being has been established in terms of increased satisfaction (5, $6)$, higher compliance $(7,8)$, patient safety $(5,6)$, enhanced psychological well-being $(9)$, improved clinical outcomes (8), and reduced healthcare-system costs $(8,10-13)$. Furthermore, involving patients in treatment decisions benefits healthcare professionals by enhancing their understanding of patients' health problems, thus contributing to more effective management of health delivery by gaining patients' trust and by enabling them to deliver individualized and tailored healthcare (14).

Worldwide, the number of people living with chronic diseases is rising, and the burden of chronic diseases is increasing rapidly. Globally, approximately one in three adults suffer from one or more chronic diseases (15). Chronically ill patients tend to have complex pathways characterized by multimorbidity and, thus, multiple contacts across the healthcare system. To meet this complexity, general practitioners (GPs) are increasingly given the primary treatment responsibility for patients with chronic disease (16). Being gatekeeper and the primary contact to healthcare, GPs play an important role in chronically ill patients' perception of being 
involved in their treatment and care. However, analyses of chronic diseases patients' involvement in their encounters with general practice appear to be lacking. The aim of this scoping review was to map the existing research regarding chronic disease patients' involvement during their encounters with general practice, with a specific focus on patients with type 2 diabetes (TD2) or obstructive pulmonary disease (COPD).

\section{Method}

\section{Protocol and registration}

This scoping review is reported according to the Preferred Reporting Items for Systematic Reviews and MetaAnalyses Extension for Scoping Reviews (Prisma-ScR). The protocol was registered in the Open Science Framework (osf.io/ynqt2) and remained unchanged during the reviewosf.io/ynqt2.

\section{Eligibility criteria}

In relation to the aim of this scoping review, studies reporting the involvement of adult patients aged 18 years or older and with TD2 or COPD were included. The core concept examined by this scoping review is patient involvement, defined as active participation in healthcare decision-making, patient involvement in healthcare consultation, factors associated with patient involvement, and patients' preference for involvement. The context is limited to general practice and their encounters with GPs. Studies reporting on patients with mental illness, patients in palliative care, and studies reporting results from multiple diagnoses, populations, or age groups and where the results were not stratified were excluded. Studies reporting patient involvement between other healthcare professionals in general practice (e.g., nurse, secretary, social and healthcare assistant) were excluded. If studies included patients with different diagnoses, patients both over and under 18 years of age, the studies were considered for inclusion only if data were stratified by age or diagnosis, respectively. Similarly, if studies included both a patient perspective and the perspectives of GPs or other healthcare professionals, the studies were included only if the patients and GPs perspectives were presented separately. Literature of any date and language was included.

\section{Information sources and search strategy}

Both systematic and explorative literature searches were used to uncover the field of research in the best possible manner. A systematic search of peer-reviewed scientific publications was conducted using the following databases: Medline, Cinahl, Psycinfo, and EMBASE. All databases were searched from August 2020 until October 2020, with the final search being performed on October 23, 2020.

The search was performed by the first author and guided by an information specialist. We used validated and pre-tested search filters as inspiration for developing our matrix $(17,18)$. The search strategy included subject indexing terms and free-text terms for title, abstract, and keyword searching. The search terms were grouped into three concepts and arranged in accordance with the PCC (population, concept, context) framework as recommend for scoping reviews (19). The full version of the search matrix is documented in Table 1. The search was performed using Boolean operators "AND" and "OR" to combine the search terms and, thus, structure the delimitation in the database. In addition, truncation was used to include several grammatical declinations. Simultaneously, we conducted an explorative chain search using reference and citation analyses 
of the publications identified by the systematic search. In addition, reference lists of included studies were screened for relevant articles, and experts' literature and libraries were also screened.

Table 1 Search matrix

\begin{tabular}{|c|c|c|}
\hline $\begin{array}{l}\text { Population: Patients with chronic } \\
\text { disease }\end{array}$ & Concept: Patient involvement & $\begin{array}{l}\text { Context: General } \\
\text { practice }\end{array}$ \\
\hline $\begin{array}{l}\text { Chronic disease (MeSH) } \\
\text { Diabetes, Mellitis type } 2 \text { (MeSH) } \\
\text { Pulmonary disease, Chronic obstructive } \\
\text { (MeSH) }\end{array}$ & $\begin{array}{l}\text { Patient participation (MeSH) } \\
\text { Decision Making (MeSH) } \\
\text { Clinical Decision-Making } \\
\text { Decision Making, shared (MeSH) } \\
\text { Self-Management (MeSH) } \\
\text { Empowerment (MeSH) } \\
\text { Patient care planning (MeSH) } \\
\text { Self-care (MeSH) } \\
\text { Patient compliance (MeSh) } \\
\text { Cooperative behavior (MeSh) } \\
\text { Physician-patient relations (MeSh) }\end{array}$ & $\begin{array}{l}\text { General } \\
\text { practitioners } \\
\text { (MeSH) } \\
\text { Physicians, } \\
\text { Family(MeSH) } \\
\text { General practise } \\
\text { (MeSH) } \\
\text { Primary health } \\
\text { care (MeSH) } \\
\text { Family practice } \\
\text { (MeSH) }\end{array}$ \\
\hline $\begin{array}{l}\text { Free text } \\
\text { (Chronic disease*) or (Chronic disorder) } \\
\text { or (Chronic illness*) or (Diabetes type } \\
\text { 2) or ( T2D) or (COPD) or (Chronic } \\
\text { pulmonary obstructive disease*) or } \\
\text { (long-term condition*) }\end{array}$ & $\begin{array}{l}\text { ((activati* or participat* or involv* or engag* or influenc* or } \\
\text { impact or perspective* or collaborat* or contribut* or } \\
\text { adherence or centered or includ* or inclusion or voice* or } \\
\text { view* or intergra* or led or partner*) adj2 (patient or client } \\
\text { or user or consumer)) } \\
\text { Or } \\
\text { ((Co-production adj2 knowledge) or shared decision making } \\
\text { or self-management or empowerment or partnership) }\end{array}$ & $\begin{array}{l}\text { (General practi*) } \\
\text { or (family practi*) } \\
\text { or (family } \\
\text { physician*) or } \\
\text { (primary care) or } \\
\text { (GP) }\end{array}$ \\
\hline
\end{tabular}

\section{Study selection}

All identified studies were uploaded to Endnote. Doublets were removed prior to importation to the reference program Covidence.org. Prior to study selection, we pilot-tested the predefined eligibility criteria in a sample of 50 articles (SBT, MM, and BN). Two authors (SBT and BN) independently screened the remaining titles and abstracts, and disagreements were resolved through discussion or via the involvement of a third author (MM). Eligibility does not necessarily have to be established before the literature search in a scoping review; eligibility criteria can be developed as the knowledge of the identifies literature grows (20). In accordance with this approach, the eligibility criteria for this scoping review were adjusted after screening the titles. 


\section{Data extraction}

Data extraction was performed independently by two reviewers (SBT, BN) using predefined data-extraction spreadsheets. Discrepancies were negotiated until consensus was reached, with a third reviewer (MM) available to resolve conflicts. Data were systematically charted by the following study characteristics: Bibliographic aims; study aims; setting; area of interest; results; conclusion.

\section{Data synthesis}

The included studies' key findings were descriptively summarized and narratively presented. First, we grouped the extracted studies by the perspectives reported (i.e., perspectives of general practitioners and patients with TD2 or COPD). We then identified patterns across the studies and presented these descriptively and narratively.

\section{Results}

\section{Study selection}

We identified a total of 12,552 studies. After de-duplication, a total of 7778 title abstract were screened, and 7721 citations were excluded due to wrong outcomes or wrong population, leaving 57 studies for full-text reading, of which 19 studies met the inclusion criteria. The process is illustrated in Figure 1.

\section{Description of included studies}

The included studies were published between 2001 and 2020. Four of the 19 studies were undertaken in Australia (21-24), three in the USA (25-27), two in Sweden $(28,29)$, Norway $(30,31)$, UK $(32,33)$, New Zealand $(34,35)$, and Belgium $(36,37)$, and one in Malaysia (38). Sixteen studies applied qualitative methods (22-24, 27-31, 33-38), one conducted a survey (26), and two studies applied mixed methods (25, 32). For data collection, semi-structured interviews, focus group interviews, telephone interviews, video recordings, and observations were used. Furthermore, the mixed-methods studies included questionnaires, interviews, and observations. The most frequent investigative methods were content $(21,28-30)$ or thematic $(22,24,31,33,37)$ analysis, whereas one study applied a grounded theory approach (27). Of the included studies, there was an underrepresentation of studies including patients with COPD because no studies contained knowledge on the involvement of patients with COPD from the patients' perspectives and only two from GPs' perspectives (31, 35). The remaining 17 studies reported on the involvement of patients with type 2 diabetes from either the patients' $(21,22,25,28,30,32,37)$ or GPs' $(23,29,31,35,36)$ views or a combination thereof $(24,26,27,33,34$, 38). In Table 2, we present the included studies' characteristics. The studies comprised 1,132 participants (843 patients and 289 GPs), with 10-322 patients with TD2 per study and 4-67 GPs. Most studies applied purposive or randomly selected sampling strategies.

Table 2. Study characteristics 


\begin{tabular}{|c|c|c|c|c|c|c|c|}
\hline $\begin{array}{l}\text { Author, } \\
\text { year of } \\
\text { publication, } \\
\text { location }\end{array}$ & Aim & $\begin{array}{l}\text { Study } \\
\text { design }\end{array}$ & $\begin{array}{l}\text { Inclusion and } \\
\text { exclusion } \\
\text { criteria }\end{array}$ & $\begin{array}{l}\text { Design/data } \\
\text { Collection } \\
\text { method }\end{array}$ & $\begin{array}{l}\text { Sampling } \\
\text { strategy }\end{array}$ & $\begin{array}{l}\text { Participants' } \\
\text { characteristics } \\
\text { (Gender, Age,) }\end{array}$ & $\begin{array}{l}\text { Data } \\
\text { analysis } \\
\text { techniqies }\end{array}$ \\
\hline $\begin{array}{l}\text { Abdulhadi, } \\
2007 \\
\text { (Sweden) }\end{array}$ & $\begin{array}{l}\text { To explore the } \\
\text { perceptions of td } 2 \\
\text { patients regarding the } \\
\text { medical encounters } \\
\text { and quality of } \\
\text { interactions with their } \\
\text { primary health-care } \\
\text { providers. }\end{array}$ & Qualitative & $\begin{array}{l}\text { Patients with } \\
\text { td2 }(\mathrm{n}=27)\end{array}$ & $\begin{array}{l}\text { Focus group } \\
\text { interview }\end{array}$ & $\begin{array}{l}\text { Purposive } \\
\text { sampling }\end{array}$ & $\begin{array}{l}13 \text { men and } 14 \\
\text { women from six } \\
\text { primary } \\
\text { healthcare } \\
\text { centres in } \\
\text { Muscat. Median } \\
\text { age (range 26- } \\
70 \text { years) }\end{array}$ & $\begin{array}{l}\text { Qualitative } \\
\text { content } \\
\text { analysis }\end{array}$ \\
\hline $\begin{array}{l}\text { Dambha- } \\
\text { Miller, } \\
2018 \text { (UK) }\end{array}$ & $\begin{array}{l}\text { To explore patients } \\
\text { views on factors } \\
\text { within patient- } \\
\text { practitioner } \\
\text { interactions that are } \\
\text { of signifigance to } \\
\text { them after diagnosis } \\
\text { and over a } 10 \text { year } \\
\text { experience of living } \\
\text { witht he disase } \\
\end{array}$ & $\begin{array}{l}\text { Mixed } \\
\text { methods }\end{array}$ & $\begin{array}{l}\text { Patints with } \\
\text { td2 }(\mathrm{n}=311) 1 \\
\text { year follow up. } \\
(\mathrm{n}=110) 10 \\
\text { year follow up. } \\
(\mathrm{n}=46) \text { both } \\
\text { times. }\end{array}$ & $\begin{array}{l}\text { Survey - Free } \\
\text { text comment. }\end{array}$ & $?$ & $\begin{array}{l}1 \text { year follow } \\
\text { up: } 196 \text { men/ } \\
142 \text { women. } \\
\text { Mean age } 60 \\
\text { years old. } 10 \\
\text { year follow up. } \\
53 \text { men/48 } \\
\text { women. mean } \\
\text { age } 72 \text { years } \\
\text { old. }\end{array}$ & $\begin{array}{l}\text { descriptive } \\
\text { analysis. } \\
\text { Cross- } \\
\text { sectoionally } \\
\text { analysis }\end{array}$ \\
\hline $\begin{array}{l}\text { Ball, } 2016 \text { ( } \\
\text { Australia) }\end{array}$ & $\begin{array}{l}\text { To examine the } \\
\text { perpections of } \\
\text { patients who have } \\
\text { been recently } \\
\text { diagnosed with TD2 } \\
\text { regarding nutrition } \\
\text { care provided by } \\
\text { primary healthcare } \\
\text { professionals }\end{array}$ & Qualitative & $\begin{array}{l}\text { Patients with } \\
\text { td2 }(n=10)\end{array}$ & $\begin{array}{l}\text { Semi- } \\
\text { structured } \\
\text { telephone } \\
\text { interviews }\end{array}$ & $\begin{array}{l}\text { Purposive } \\
\text { sampling }\end{array}$ & $\begin{array}{l}3 \text { male, } 7 \\
\text { female, age } \\
\text { range }(27-74) \\
\text { years. }\end{array}$ & $\begin{array}{l}\text { Content } \\
\text { analysis and } \\
\text { meta- } \\
\text { synthesis of } \\
\text { findings } \\
\text { over time }\end{array}$ \\
\hline $\begin{array}{l}\text { Burridge, } \\
2016 \\
\text { (Australia) }\end{array}$ & $\begin{array}{l}\text { Patients perceptions } \\
\text { and experiences of } \\
\text { TD2 selfcare and } \\
\text { engamgement with } \\
\text { Gp-led intergrated } \\
\text { diabetes care }\end{array}$ & Qualitative & $\begin{array}{l}\text { Patients with } \\
\text { td2 }(n=30)\end{array}$ & Interviews & $\begin{array}{l}\text { purposeive } \\
\text { sampling }\end{array}$ & $\begin{array}{l}\text { Mean age } \\
(60,2) \text { years } \\
\text { old. } 14 \text { female } \\
\text { and } 16 \text { male. }\end{array}$ & $\begin{array}{l}\text { Thematic } \\
\text { analysys }\end{array}$ \\
\hline $\begin{array}{l}\text { Oftedal, } \\
2020 \\
\text { (Norway) }\end{array}$ & $\begin{array}{l}\text { How adults with TD2 } \\
\text { perceive different } \\
\text { attributes of support } \\
\text { provided by } \\
\text { healthcare } \\
\text { practitioners and how } \\
\text { various attributes of } \\
\text { support can influence } \\
\text { peoples motication to } \\
\text { self-manage their } \\
\text { diseases }\end{array}$ & Qualitative & $\begin{array}{l}\text { patients with } \\
\text { td2 }(\mathrm{n}=19)\end{array}$ & $\begin{array}{l}\text { Focus group } \\
\text { interviews }\end{array}$ & $\begin{array}{l}\text { purposive } \\
\text { sample }\end{array}$ & $\begin{array}{l}12 \text { male, } 7 \\
\text { female. Median } \\
\text { age } 54,52,42\end{array}$ & $\begin{array}{l}\text { Content } \\
\text { analysis }\end{array}$ \\
\hline $\begin{array}{l}\text { Parchman, } \\
2010 \text { (USA) }\end{array}$ & $\begin{array}{l}\text { To examine a causal } \\
\text { model linking } \\
\text { participatory decision } \\
\text { making to improved } \\
\text { clinical outcomes that } \\
\text { included patient } \\
\text { actitivation and }\end{array}$ & $\begin{array}{l}\text { Mixed } \\
\text { methods }\end{array}$ & $\begin{array}{l}\text { patients with } \\
\text { type } 2 \\
\text { diabetes } \\
(\mathrm{n}=144)\end{array}$ & $\begin{array}{l}\text { Observatations } \\
\text { and Survery } \\
\text { quistionarie. }\end{array}$ & $?$ & $\begin{array}{l}\text { Patients: mean } \\
\text { age 57,7 years. } \\
61 \% \text { female and } \\
39 \% \text { male. }\end{array}$ & LGC curve \\
\hline
\end{tabular}




\begin{tabular}{|c|c|c|c|c|c|c|c|}
\hline & $\begin{array}{l}\text { medication } \\
\text { adherence. }\end{array}$ & & & & & & \\
\hline $\begin{array}{l}\text { Vermeire, } \\
2003 \\
\text { (Belgium) }\end{array}$ & $\begin{array}{l}\text { To examine the health } \\
\text { beliefs of people } \\
\text { living with td2, the } \\
\text { way they } \\
\text { communicate about it, } \\
\text { and the problem they } \\
\text { encounter in adhering } \\
\text { to therapeutic } \\
\text { regimens }\end{array}$ & Qualitative & $\begin{array}{l}\text { Type } 2 \\
\text { diabetes } \\
\text { patients. } \\
(\mathrm{n}=46)\end{array}$ & $\begin{array}{l}\text { Focus group } \\
\text { interviews and } \\
\text { observations }\end{array}$ & $\begin{array}{l}\text { Focus } \\
\text { groups } \\
\text { divided by } \\
\text { gender. }\end{array}$ & $\begin{array}{l}21 \text { male, } 25 \\
\text { female. Age } \\
\text { range } 40-80 .\end{array}$ & $\begin{array}{l}\text { Thematic } \\
\text { analysis }\end{array}$ \\
\hline $\begin{array}{l}\text { Abdulhadi, } \\
2013, \\
\text { (Sweden) }\end{array}$ & $\begin{array}{l}\text { To explore the } \\
\text { experiences of } \\
\text { primary health-care } \\
\text { providers of their } \\
\text { encounters with } \\
\text { patients with TD2, and } \\
\text { their preferenes and } \\
\text { suggestions for future } \\
\text { improvement of } \\
\text { diabetes care }\end{array}$ & Qualitative & $\begin{array}{l}\text { General } \\
\text { practitioner } \\
(\mathrm{n}=19)\end{array}$ & $\begin{array}{l}\text { Semi- } \\
\text { structured } \\
\text { interview }\end{array}$ & $\begin{array}{l}\text { purposive } \\
\text { sampling }\end{array}$ & $\begin{array}{l}8 \text { female, } 11 \\
\text { male, age } \\
\text { range (29-55) } \\
\text { years }\end{array}$ & $\begin{array}{l}\text { Qualitative } \\
\text { content } \\
\text { analysis }\end{array}$ \\
\hline $\begin{array}{l}\text { Halliwell, } \\
2016 \text { (New } \\
\text { Zealand) }\end{array}$ & $\begin{array}{l}\text { To identify strategies } \\
\text { that general } \\
\text { practitioners can use } \\
\text { to facilitate } \\
\text { discussions of } \\
\text { prognosis with } \\
\text { patients who have } \\
\text { COPD }\end{array}$ & Qualitative & $\begin{array}{l}\text { General } \\
\text { practitioners } \\
(n=15)\end{array}$ & $\begin{array}{l}\text { Telephone } \\
\text { interviews }\end{array}$ & $\begin{array}{l}\text { Purposive } \\
\text { sampling }\end{array}$ & $\begin{array}{l}\text { GP: } 7 \text { women } \\
\text { and } 8 \text { men. Age } \\
\text { range } 31-60\end{array}$ & $\begin{array}{l}\text { General } \\
\text { inductive } \\
\text { approach }\end{array}$ \\
\hline $\begin{array}{l}\text { Laue, } 2016 \\
\text { (Norway) }\end{array}$ & $\begin{array}{l}\text { To explore the } \\
\text { decision-making of } \\
\text { general practitioners } \\
\text { concerning treatment } \\
\text { with antibiotics } \\
\text { and/or oral } \\
\text { corticosteroids and } \\
\text { hospitilization for } \\
\text { COPD patients with } \\
\text { Exerbations }\end{array}$ & Qualitative & $\begin{array}{l}\text { General } \\
\text { practitioners } \\
(n=53)\end{array}$ & $\begin{array}{l}\text { Focus group } \\
\text { interview }\end{array}$ & $\begin{array}{l}\text { purposive } \\
\text { sampling }\end{array}$ & ? & $\begin{array}{l}\text { Thematic } \\
\text { analysys }\end{array}$ \\
\hline $\begin{array}{l}\text { Shortus, } \\
2013 \\
\text { (Australia) }\end{array}$ & $\begin{array}{l}\text { To investigate } \\
\text { provider perspectives } \\
\text { on the role of patient } \\
\text { involvement in } \\
\text { chronic disease } \\
\text { decision making }\end{array}$ & Qualitative & $\begin{array}{l}\text { general } \\
\text { practitioner } \\
(\mathrm{n}=19)\end{array}$ & interviews & $\begin{array}{l}\text { purposive } \\
\text { sampling }\end{array}$ & ? & $\begin{array}{l}\text { Grounded } \\
\text { theory }\end{array}$ \\
\hline $\begin{array}{l}\text { Wens, } 2005 \\
\text { (Belgium) }\end{array}$ & $\begin{array}{l}\text { To examine } \\
\text { explicitely the } \\
\text { physicians } \\
\text { expectations of their } \\
\text { diabetes patient } \\
\text { compliance/adhernce. } \\
\text { Objectives: 1) elicit } \\
\text { problem physicians } \\
\text { encounter with td2 } \\
\text { diabets patients } \\
\text { adherende to }\end{array}$ & Qualitative & $\begin{array}{l}\text { general } \\
\text { pracitioners } \\
(\mathrm{n}=40)\end{array}$ & $\begin{array}{l}\text { Focus group } \\
\text { interviews and } \\
\text { observations }\end{array}$ & NO & $\begin{array}{l}40 \text { general } \\
\text { practitioners. } \\
26,14 \text { men. } \\
\text { Mean age } 45,3 \text {. } \\
\text { mean years in } \\
\text { practice } 18,4 \text { ) }\end{array}$ & $\begin{array}{l}\text { content } \\
\text { analysis }\end{array}$ \\
\hline
\end{tabular}




\begin{tabular}{|c|c|c|c|c|c|c|c|}
\hline & $\begin{array}{l}\text { treatment } \\
\text { recommendations; 2) } \\
\text { to search for } \\
\text { soluations and 3) to } \\
\text { discover escape } \\
\text { mechanisms in case } \\
\text { of frustration }\end{array}$ & & & & & & \\
\hline $\begin{array}{l}\text { Dao, } 2019 \\
\text { (Australia) }\end{array}$ & $\begin{array}{l}\text { To explore the factors } \\
\text { influencing self- } \\
\text { management of TD2 } \\
\text { in patients attending } \\
\text { general practice in } \\
\text { sputh west sydney } \\
\text { from both a patient } \\
\text { and provider } \\
\text { perspective. A } \\
\text { secondary aim was to } \\
\text { assess how consistent } \\
\text { the findigs were with } \\
\text { the socio-ecological } \\
\text { model }\end{array}$ & Qualitative & $\begin{array}{l}\text { Patients with } \\
\text { td2 }(\mathrm{n}=10 \\
\quad \text { General } \\
\text { practitioner } \\
(\mathrm{n}=4)\end{array}$ & $\begin{array}{l}\text { semi- } \\
\text { structured } \\
\text { interviews }\end{array}$ & $\begin{array}{l}\text { Purposive } \\
\text { sampling }\end{array}$ & $\begin{array}{l}\text { Patient group: } 6 \\
\text { female and } 4 \\
\text { male. Age } \\
\text { range } 30-79 . \\
\text { GP: } 6 \text { female, } \\
\text { and } 4 \text { male, age } \\
\text { range } 30-79 .\end{array}$ & $\begin{array}{l}\text { Thematic } \\
\text { analysis }\end{array}$ \\
\hline $\begin{array}{l}\text { Dowell, } \\
2018 \text { (New } \\
\text { Zealand) }\end{array}$ & $\begin{array}{l}\text { To observe in detal } \\
\text { the primary care } \\
\text { interactions and } \\
\text { communications of } \\
\text { patients with newly } \\
\text { diagnosed diabetes } \\
\text { over time. In addition } \\
\text { to identify key ponts } \\
\text { on the process where } \\
\text { miscommunication } \\
\text { might occour }\end{array}$ & Qualitative & $\begin{array}{l}\text { Patients with } \\
\text { TD2(n=32) } \\
\text { General } \\
\text { practitioner } \\
(\mathrm{n}=?)\end{array}$ & $\begin{array}{l}\text { video } \\
\text { Recording }\end{array}$ & $\begin{array}{l}\text { purposively } \\
\text { samling }\end{array}$ & $?$ & $\begin{array}{l}\text { ethnography } \\
\text { and } \\
\text { interaction } \\
\text { analysis }\end{array}$ \\
\hline $\begin{array}{l}\text { Grant, } 2016 \\
\text { (USA) }\end{array}$ & $\begin{array}{l}\text { To examine how } \\
\text { patients with TD2 and } \\
\text { their primary care } \\
\text { physicians identify } \\
\text { and discuss visits } \\
\text { prior to and during } \\
\text { visits. }\end{array}$ & Qualitative & $\begin{array}{l}\text { Patients with } \\
\text { TD2 }(\mathrm{n}=29) \\
\quad \text { General } \\
\text { practitioner } \\
(\mathrm{n}=67)\end{array}$ & $\begin{array}{l}\text { Qualitative } \\
\text { interviews and } \\
\text { focus group }\end{array}$ & $\begin{array}{l}\text { purposeive } \\
\text { sampling }\end{array}$ & $\begin{array}{l}\text { Patients: Age } \\
\text { range } 35-80) 14 \\
\text { kvinder and } 15 \\
\text { men. Primary } \\
\text { care providers } \\
\text { ( } 61 \% \text { women. }\end{array}$ & $\begin{array}{l}\text { Modified } \\
\text { grounded } \\
\text { theory } \\
\text { aapproach } \\
\text { with a } \\
\text { inductive } \\
\text { approach }\end{array}$ \\
\hline $\begin{array}{l}\text { Heislter, } \\
2003 \text { (USA) }\end{array}$ & $\begin{array}{l}\text { To assess the extent } \\
\text { to which patients wit } \\
\text { TD2 agree with their } \\
\text { primary care provider } \\
\text { on diabets treatment } \\
\text { goals and strategies, } \\
\text { the factors that } \\
\text { predict agreement nd } \\
\text { whether greater } \\
\text { agreement is } \\
\text { associated with better } \\
\text { patient self- } \\
\text { manamgenet of } \\
\text { diabetes }\end{array}$ & Survey & $\begin{array}{l}\text { Patients with } \\
\text { TD2 }(\mathrm{n}=123) \\
\text { General } \\
\text { practitioner } \\
(\mathrm{n}=50)\end{array}$ & Survey & $\begin{array}{l}\text { randomly } \\
\text { sample }\end{array}$ & $\begin{array}{l}\text { patient: mean } \\
\text { age } 65,81 \% \\
\text { male. Provider } \\
\text { mean age } 40, \\
56 \% \text { men }\end{array}$ & $\begin{array}{l}\text { descriptive } \\
\text { statistics }\end{array}$ \\
\hline $\begin{array}{l}\text { Pooley, } \\
2001 \text { (UK) }\end{array}$ & $\begin{array}{l}\text { To explore people } \\
\text { with td } 2 \text { and } \\
\text { healthcare }\end{array}$ & Qualitative & $\begin{array}{l}\text { Patients with } \\
\text { type } 2 \\
\text { diabetes }\end{array}$ & $\begin{array}{l}\text { Focus group } \\
\text { interviews }\end{array}$ & $\begin{array}{l}\text { Randomly } \\
\text { selected. }\end{array}$ & $?$ & $\begin{array}{l}\text { Thematic } \\
\text { analysis }\end{array}$ \\
\hline
\end{tabular}




\begin{tabular}{|c|c|c|c|c|c|c|c|}
\hline & $\begin{array}{l}\text { professionals who } \\
\text { deliever their } \\
\text { diabetes care. To } \\
\text { explore the issues } \\
\text { that they perceieve as } \\
\text { central to effective } \\
\text { management of } \\
\text { diabetes, primarily } \\
\text { within a primary care } \\
\text { setting }\end{array}$ & & $\begin{array}{l}(\mathrm{n}=47) \\
\text { General } \\
\text { practitioners } \\
(\mathrm{n}=7)\end{array}$ & & & & \\
\hline $\begin{array}{l}\text { Syed, } 2017 \\
\text { (Malysia) }\end{array}$ & $\begin{array}{l}\text { To investigate } \\
\text { whether the use of } \\
\text { apatient decision aid } \\
\text { for insulin initiation } \\
\text { fulfils its purpose of } \\
\text { facilitating patient- } \\
\text { centered decision- } \\
\text { making through } \\
\text { identifying how } \\
\text { doctors and patients } \\
\text { interact when using } \\
\text { the PDA during } \\
\text { Primary care } \\
\text { consultations }\end{array}$ & Qualitative & $\begin{array}{l}\text { Type } 2 \\
\text { diabetes } \\
\text { patients } \\
(\mathrm{n}=15) \text { general } \\
\text { practitioners } \\
(\mathrm{n}=15)\end{array}$ & $\begin{array}{l}\text { Audio } \\
\text { recording }\end{array}$ & $\begin{array}{l}\text { purposive } \\
\text { sampling }\end{array}$ & ? & ? \\
\hline
\end{tabular}

\section{Narrative synthesis}

\section{Patients' perspectives}

Patients reported the importance of GPs providing them with sufficient time for the consultations and explaining or discussing things with them. It was essential that the GPs not were too rushed and preoccupied with their own agendas under time-pressure constraints $(21,22,27,32,33)$. The lack of time to deal effectively with patients' concerns and the beliefs among the patients were repeatedly mentioned (33). Furthermore, the patients stated that their tendency to express their priorities nearer to the end of the visit, which left little time to fully address their concerns, was a consequence of time constraints (27). The patients expressed that they wished for all the time they required and that their GPs were never in a rush and had time to explain and discuss treatment decisions (22). Similarly, the patients stated that an unfriendly environment with poor attention and lack of eye contact with the GP prevented them from asking questions and expressing their concerns during consultations and made the encounters more doctor centered; patients felt overwhelmed by the inability to participate in the medical dialogue or express concerns regarding their treatment. (28). The relational continuity of care was also important to the patients, and they preferred to see the same GP at each consultation. The patients expressed that they would benefit from the continuity in terms of increased familiarity with their circumstances $(22,28,32,33)$. In addition, the patients considered it problematic if they did not see the same GP every time because seeing the same GP would make it easier for them to discuss their problems and be more involved in treatment decisions (32). The patients experienced that GPs differ in their behavior and methods of providing care and information, and the patients preferred to build an ongoing relationship with their GP to increase their ability to be more active in the treatment decision-making (28). This ongoing relationship was considered a partnership $(22,27,30,33,37)$ that was defined as when the 
competence of the GPs and the patients' knowledge complemented each other. The patients wanted to cooperate with their GP but found it highly difficult if their needs were not listened to (30). Furthermore, patients reported that their GPs paid too little attention to their health beliefs and to the opinions and concepts they held on medicine in general, their illness, and on medicine-taking (37). Patients identified key factors that were associated with more effective discussion of their visit's priorities, including GPs' willingness to be flexible in the flow of discussion topics, and the extent to which their GPs listened to their concerns (27). It was evident that an active patient/provider alliance was important for engaging the patients in the work of disease management but likely also a critical factor in sustaining the long-term collective work that diabetes management requires (22). Low literacy was mentioned as a barrier for being involved in treatment decisions because the patients believed that they had to accept what has been demonstrated to them. Hence, they felt unable to be more active during consultations (28). However, identifying visits' priorities in advance of a visit enhanced a proactive and collaborative approach, made it possible for the patients to bring what they wanted to discuss, and did not prevent the GPs from talking about what they wanted to express. Thus, a personalized approach offered by GPs was valued (22), and the patients expressed a wish that the GPs should be better at simply listening in a more holistic approach (30).

\section{General practitioners' perspectives}

High workload was mentioned by GPs as a major problem affecting their interactions with the patients (29) because building good relationships with patients takes time (24). GPs expressed the negative impact of time constraints on the ideal goal of fully electing patient priorities; being in a rush, they often had their own agenda overriding the patient's agendas (27). A good relationship with patients was considered important in relation to involving them in treatment decisions $(24,29,31,35,36)$. A long-standing relationship with good rapport facilitates discussions about prognoses, improves rapport, increases the number of topics GP and patients can discuss in more honest detail, and enhances GPs' likelihood of getting patients to ask more questions $(24,35)$. The GPs' knowledge about their patients appeared to be important in assessing whether they could rely on the patient's own judgment about the necessity for treatment and hospitalization. They believed that the patients were rather good at assessing their treatment and hospitalization needs themselves (31). Some GPs suggested that there should be a personal interest of healthcare providers in the care and to show interest to the patients. Furthermore, they proposed avoiding giving instructions to the patients but, rather, have good communications and respect their concerns; such an approach would be a more useful way to correct the patients' understanding of their disease and gain their cooperation (29). The GPs indicated that they favored active involvement of the patient's experiential knowledge due to having lived with the disease $(31,34)$ not necessarily reflecting a biomedical need but also the requirement for relieving anxiety and meeting challenges in the patients' social lives. Consequently, there could be discrepancies between the GPs' and patients' judgments, which the GPs had to balance. According to the GPs, a lack of patients' consent to treatment or hospital referral seemed particularly challenging because it could increase their concerns (31).

The GPs reported that treatment in primary care was more effective when patients came prepared, whereas a lack of preparation by the patient tended to create barriers to clinical care due to inefficient time use. GPs noted that a tool to empower patients to help them formulate their top priorities at consultations would be helpful, and the GPs liked the idea of pre-visit preparation (27). The GPs acknowledged that there should be potential for flexibility in the application of guidelines when managing patients' diseases and that involving patients in

Page 10/18 
decision-making was itself an important consideration in attempting to deliver high-quality care. However, they believed that it was more caring to insist upon treating a patient's disease than to respect any patient preference and that they should, therefore, endeavor to persuade patients to accept their advice. The GPs saw their main responsibility as doing whatever was necessary to minimize the possibility of achieving less-thanideal outcomes. GPs often experienced a conflict between the two professional responsibilities of achieving ideal health outcomes for their patients and respecting their patients' rights to make decisions where compromise is often necessary (31).

\section{Discussion}

\section{Principal findings}

Across studies and perspectives, our findings indicate that time at consultation, relational continuity, and a good GP-patient relationship are considered important aspects for providing and facilitating patient involvement. These findings are in line with research showing that continuity in care, a supportive consultation environment with a warm and caring GP, and a good patient-GP interaction is particularly important in chronic disease management (39-42).

For the patients, it is important that their GP pay attention to their health beliefs, opinions, and concepts they hold about their treatments, illnesses, and medicines, corroborating findings from Kennedy et al., who found that healthcare providers' understanding of their patients' healthcare beliefs, values, and preferences is considered important by both patients and healthcare providers. If these providers listen and communicate with patients, they are more likely to develop a shared understanding that may improve future decision-making (43). This approach is also supported by the findings of both Mosnier-Pudar and McMillan $(44,45)$, who also found that the patients' beliefs and opinions regarding their disease and treatment affect their selfmanagement, and that exploring patients' beliefs and values is crucial is to understanding how to provide patient-centered care. However, GPs tend to experience conflicts between their professional responsibilities of achieving what they consider ideal health outcomes for their patients and respecting their patients' health beliefs and their rights to be involved in decisions. Abu Hassan et al. found that exploring patients' concerns and beliefs in relation to treatment is crucial to assist physicians in delivering patient-centered care because negative concerns and beliefs towards treatments or decisions made by the physician might cause barriers to accepting the treatment (46). Thus, patients' knowledge and health beliefs and GPs personal knowledge about a specific patient should be acknowledged as a conceptual resource for patient involvement, but how the GPs should balance their own and patients' preferences should be explored further. However, these aspects apply mainly to patients with type 2 diabetes and their GPs because no studies were found reporting on patients with COPD, and only three studies reported on GPs' perspectives on the involvement of patients with COPD. This literature gap is of concern, given the association between stigma-related experiences and important patient outcomes (47) and the fact that there are many unmet healthcare needs among patients with COPD (48). Furthermore, research shows that many people with lung disease have faced stigma due to their condition, and there is a lack of awareness of this aspect within research (49). Furthermore, patients with lung disease tend to feel isolated, which makes it even more important to engage patients with COPD to be more involved in treatment decisions (50). Thus, the focus of the included studies indicates that focus and action must be 
directed towards research exploring patients with COPD perspectives on patient involvement in general practice.

\section{Strengths and limitations}

This scoping review was designed and reported in line with the recommendations of the PRISMA-ScR statement. We searched multiple databases, and a thorough search strategy was designed iteratively by the research team and an information specialist to account for the three different dimensions of the search (patients with diabetes type 2 or COPD, patient's involvement, and general practice). All aspects of data collection, extraction, and analysis were carried out independently by two researchers, with a third party available for mediation in cases of disagreements. The primary limitation of this scoping review is the sparse literature related to our objectives. We did not assess the quality of the included studies because this is not typically a part of a scoping review due to an effort to maintain a wide perspective and include studies with different methods and designs.

\section{Conclusion}

Time at consultation, relational continuity, and a good GP-patient relationship was considered important aspects in relation to providing and facilitating patient involvement. Furthermore, conflicts between GPs' professional responsibility of achieving the best health outcome for their patients and respecting patients' health beliefs is a relevant factor in patient involvement. The included studies of knowledge within patient involvement in general practice clearly indicate that focus and action must be directed towards research exploring COPD patients' perspectives regarding their involvement in general practice.

\section{Declarations}

\section{Ethics approval and consent to participate}

n/a

\section{Consent for publication}

$\mathrm{n} / \mathrm{a}$

\section{Availability of data and material}

Full search string available as supplementary material

\section{Competing interests}

None

\section{Funding}

This project is funded by University of Southern Denmark (Human Health)

\section{Authors' contributions}


All authors have contributed substantially to this paper.

Design of protocol $\quad$ SBT, MM, MSR, BN

Search strategy and search STB, MM, MSR, BN

TiAb screening $\quad S B T, B N$

Full text reading $\quad \mathrm{SBT}, \mathrm{BN}$

Data extraction, analysis, and synthesis $\quad$ SBT, BN

Manuscript $\quad$ SBT, MM, BN

\section{Acknowledgements}

$\mathrm{n} / \mathrm{a}$

\section{References}

1. Boote J, Wong R, Booth A. "Talking the talk or walking the walk?" A bibliometric review of the literature on public involvement in health research published between 1995 and 2009. Heal Expect 2015.

2. KH. P, Schou L, Piil K, Jarden M. Current trends in patient and public involvement in cancer research: A systematic review. Health Expectations. 2019.

3. Kennedy AP, Rogers AE. Improving patient involvement in chronic disease management: the views of patients, GPs and specialists on a guidebook for ulcerative colitis. Patient Educ Couns. 2002;47(3):257-63. Epub 2002/06/29. doi: 10.1016/s0738-3991(01)00228-2. PubMed PMID: 12088604.

4. Longtin Y, Sax H, Leape LL, Sheridan SE, Donaldson L, Pittet D. Patient participation: current knowledge and applicability to patient safety. Mayo Clinic proceedings. 2010;85(1):53-62. doi:

10.4065/mcp.2009.0248. PubMed PMID: 20042562.

5. Shay LA, Lafata JE. Where is the evidence? A systematic review of shared decision making and patient outcomes. Med Decis Making. 2015;35(1):114-31. Epub 2014/10/30. doi: 10.1177/0272989x14551638. PubMed PMID: 25351843; PubMed Central PMCID: PMCPMC4270851.

6. Stacey D, Légaré F, Lewis K, Barry MJ, Bennett CL, Eden KB, et al. Decision aids for people facing health treatment or screening decisions. Cochrane Database Syst Rev. 2017;4(4):Cd001431. Epub 2017/04/13. doi: 10.1002/14651858.CD001431.pub5. PubMed PMID: 28402085.

7. Aljumah K, Hassali MA. Impact of pharmacist intervention on adherence and measurable patient outcomes among depressed patients: a randomised controlled study. BMC Psychiatry. 2015;15:219. Epub 2015/09/18. doi: 10.1186/s12888-015-0605-8. PubMed PMID: 26376830; PubMed Central PMCID: PMCPMC4574071.

8. Wilson SR, Strub P, Buist AS, Knowles SB, Lavori PW, Lapidus J, et al. Shared treatment decision making improves adherence and outcomes in poorly controlled asthma. Am J Respir Crit Care Med.

2010;181(6):566-77. Epub 2009/12/19. doi: 10.1164/rccm.200906-09070C. PubMed PMID: 20019345; PubMed Central PMCID: PMCPMC2841026. 
9. Bailey RA, Pfeifer M, Shillington AC, Harshaw Q, Funnell MM, VanWingen J, et al. Effect of a patient decision aid (PDA) for type 2 diabetes on knowledge, decisional self-efficacy, and decisional conflict. BMC Health Serv Res. 2016;16:10. Epub 2016/01/15. doi: 10.1186/s12913-016-1262-4. PubMed PMID: 26762150; PubMed Central PMCID: PMCPMC4712511.

10. Longtin Y, Sax H, Leape LL, Sheridan SE, Donaldson L, Pittet D. Patient Participation: Current knowledge and applicability to patient safety- 2010;85 (1):53-62.

11. Florin J, Ehrenberg A, Ehnfors M. Patient participation in clinical decision-making in nursing: $A$ comparative study of nurses' and patients' perceptions. Journal of Clinical Nursing. 2006;Dec;15(12):1498508. doi: 10.1111/j.1365-2702.2005.01464.x.

12. Guadagnoli E, Ward P. Patient participation in decision-making. Social Science \& Medicine. 1998;47(3). doi: https://doi.org/10.1016/S0277-9536(98)00059-8.

13. Wensing M, Grol R. Patients' Views on Healthcare: A Driving Force for Improvement in Disease Management. 2000;7(3, p117-125. 9). doi: 10.2165/00115677-200007030-00001.

14. Department of Health. Patient and Public Involvement in Health: The Evidence for Policy Implementation. Department of Health; London, UK. 2004.

15. Hajat C, Stein E. The global burden of multiple chronic conditions: A narrative review. Prev Med Rep. 2018;12:284-93. doi: 10.1016/j.pmedr.2018.10.008. PubMed PMID: 30406006.

16. REGIONERNES LØNNINGS- OG TAKSTNAEVN PRAKTISERENDE LAEGERS ORGANISATION. Collective agreement between danish regions and general practice [Overenskomst om almen praksis]. 2018;1. udgave, 1. oplag 2018. doi: ISBN: 978-87-7891-217-6.

17. Gill PJ, Roberts NW, Wang KY, Heneghan C. Development of a search filter for identifying studies completed in primary care. Fam Pract. 2014;31(6):739-45. Epub 2014/10/20. doi: 10.1093/fampra/cmu066. PubMed PMID: 25326923.

18. Rogers M, Bethel A, Boddy K. Development and testing of a medline search filter for identifying patient and public involvement in health research. Health Info Libr J. 2017;34(2):125-33. Epub 2017/01/04. doi: 10.1111/hir.12157. PubMed PMID: 28042699; PubMed Central PMCID: PMCPMC6191645.

19. Institute. TJB. The Joanna Briggs Institute Reviewers' Manual 2015: Methodology for JBI scoping reviews: Joanne Briggs Inst.; 2015 2015;1-24.

20. Arksey H, O'Malley L. Scoping studies: towards a methodological framework. International Journal of Social Research Methodology. 2005;8(1):19-32. doi: 10.1080/1364557032000119616.

21. Ball L, Davmor R, Leveritt M, Desbrow B, Ehrlich C, Chaboyer W. Understanding the nutrition care needs of patients newly diagnosed with type 2 diabetes: a need for open communication and patient-focussed consultations. Australian Journal of Primary Health. 2016;22(5):416-22. doi: 10.1071/PY15063. PubMed PMID: 118891267. Language: English. Entry Date: 20161021. Revision Date: 20191111. Publication Type: Article.

22. Burridge LH, Foster MM, Donald M, Zhang J, Russell AW, Jackson CL. Making sense of change: patients' views of diabetes and GP-led integrated diabetes care. Health expectations : an international journal of public participation in health care and health policy. 2016;19(1):74-86. doi: https://dx.doi.org/10.1111/hex.12331. 
23. Shortus T, Kemp L, McKenzie S, Harris M. 'Managing patient involvement': Provider perspectives on diabetes decision-making. Health Expectations: An International Journal of Public Participation in Health Care \& Health Policy. 2013;16(2):189-98. doi: http://dx.doi.org/10.1111/j.1369-7625.2011.00700.x.

24. Dao J, Spooner C, Lo W, Harris MF. Factors influencing self-management in patients with type 2 diabetes in general practice: A qualitative study. Australian Journal of Primary Health. 2019;25(2):176-84. doi: http://dx.doi.org/10.1071/PY18095.

25. Parchman ML, Zeber JE, Palmer RF, Parchman ML, Zeber JE, Palmer RF. Participatory decision making, patient activation, medication adherence, and intermediate clinical outcomes in type 2 diabetes: a STARNet study. Annals of Family Medicine. 2010;8(5):410-7. doi: 10.1370/afm.1161. PubMed PMID: 104923969. Language: English. Entry Date: 20110107. Revision Date: 20161116. Publication Type: journal article.

26. Heisler M, Vijan S, Anderson RM, Ubel PA, Bernstein SJ, Hofer TP. When do patients and their physicians agree on diabetes treatment goals and strategies, and what difference does it make? Journal of General Internal Medicine. 2003;18(11):893-902. doi: http://dx.doi.org/10.1046/j.1525-1497.2003.21132.x.

27. Grant RW, Altschuler A, Uratsu CS, Sanchez G, Schmittdiel JA, Adams AS, et al. Primary care visit preparation and communication for patients with poorly controlled diabetes: A qualitative study of patients and physicians. Primary care diabetes. 2017;11(2):148-53. doi:

https://dx.doi.org/10.1016/j.pcd.2016.11.003.

28. Abdulhadi N, Al Shafaee M, Freudenthal S, Ostenson C-G, Wahlstrom R. Patient-provider interaction from the perspectives of type 2 diabetes patients in Muscat, Oman: a qualitative study. BMC health services research. 2007;7:162.

29. Abdulhadi NM, Al-Shafaee MA, Wahlstrom R, Hjelm K. Doctors' and nurses' views on patient care for type 2 diabetes: an interview study in primary health care in Oman. Primary health care research \& development. 2013;14(3):258-69.

30. Oftedal B, Karlsen B, Bru E. Perceived support from healthcare practitioners among adults with type 2 diabetes. Journal of Advanced Nursing. 2010;66(7):1500-9. doi: http://dx.doi.org/10.1111/j.13652648.2010.05329.x.

31. Laue J, Melbye H, Halvorsen PA, Andreeva EA, Godycki-Cwirko M, Wollny A, et al. How do general practitioners implement decision-making regarding COPD patients with exacerbations? An international focus group study. International Journal of COPD. 2016;11(1):3109-19. doi: http://dx.doi.org/10.2147/COPD.S118856.

32. Dambha-Miller H, Silarova B, Irving G, Kinmonth AL, Griffin SJ. Patients' views on interactions with practitioners for type 2 diabetes: a longitudinal qualitative study in primary care over 10 years. The British journal of general practice : the journal of the Royal College of General Practitioners. 2018;68(666):e36e43. doi: https://dx.doi.org/10.3399/bjgp17X693917.

33. Pooley CG, Gerrard C, Hollis S, Morton S, Astbury J. 'Oh it's a wonderful practice... you can talk to them': a qualitative study of patients' and health professionals' views on the management of type 2 diabetes. Health \& social care in the community. 2001;9(5):318-26.

34. Dowell A, Stubbe M, Macdonald L, Tester R, Gray L, Vernall S, et al. A Longitudinal Study of Interactions Between Health Professionals and People With Newly Diagnosed Diabetes. United States: 2018 1544-1717 
(electronic) 1544-1717 Contract No.: 1.

35. Halliwell J, Mulcahy P, Buetow S, Bray Y, Coster G, Osman LM. GP discussion of prognosis with patients with severe chronic obstructive pulmonary disease: a qualitative study. The British journal of general practice : the journal of the Royal College of General Practitioners. 2004;54(509):904-8.

36. Wens J, Vermeire E, Royen PV, Sabbe B, Denekens J. GPs' perspectives of type 2 diabetes patients' adherence to treatment: A qualitative analysis of barriers and solutions. BMC family practice. 2005;6(1):20.

37. Vermeire E, Van Royen P, Coenen S, Wens J, Denekens J. The adherence of type 2 diabetes patients to their therapeutic regimens: a qualitative study from the patient's perspective. Practical Diabetes International. 2003;20(6):209-14. doi: 10.1002/pdi.505. PubMed PMID: 106650385. Language: English. Entry Date: 20041008. Revision Date: 20200708. Publication Type: Journal Article.

38. Syed A, Don ZM, Ng CJ, Lee YK, Khoo EM, Lee PY, et al. Using a patient decision aid for insulin initiation in patients with type 2 diabetes: A qualitative analysis of doctor-patient conversations in primary care consultations in Malaysia. BMJ Open. 2017;7(5):e014260. doi: http://dx.doi.org/10.1136/bmjopen-2016014260.

39. Auerbach SM, Clore JN, Kiesler DJ, Orr T, Pegg PO, Quick BG, et al. Relation of diabetic patients' healthrelated control appraisals and physician-patient interpersonal impacts to patients' metabolic control and satisfaction with treatment. J Behav Med. 2002;25(1):17-31. Epub 2002/02/16. doi:

10.1023/a:1013585617303. PubMed PMID: 11845556.

40. Wens J, Vermeire E, Royen PV, Sabbe B, Denekens J. GPs' perspectives of type 2 diabetes patients' adherence to treatment: A qualitative analysis of barriers and solutions. BMC Fam Pract. 2005;6(1):20. Epub 2005/05/14. doi: 10.1186/1471-2296-6-20. PubMed PMID: 15890071; PubMed Central PMCID: PMCPMC1156882.

41. Holmström I, Halford C, Rosenqvist U. Swedish health care professionals' diverse understandings of diabetes care. Patient Educ Couns. 2003;51(1):53-8. Epub 2003/08/14. doi: 10.1016/s07383991(02)00212-4. PubMed PMID: 12915280.

42. Campbell SM, Hann M, Hacker J, Burns C, Oliver D, Thapar A, et al. Identifying predictors of high quality care in English general practice: observational study. BMJ. 2001;323(7316):784. doi:

10.1136/bmj.323.7316.784.

43. Kennedy BM, Rehman M, Johnson WD, Magee MB, Leonard R, Katzmarzyk PT. Healthcare Providers versus Patients' Understanding of Health Beliefs and Values. Patient Exp J. 2017;4(3):29-37. PubMed PMID: 29308429.

44. McMillan SS, Kendall E, Sav A, King MA, Whitty JA, Kelly F, et al. Patient-centered approaches to health care: a systematic review of randomized controlled trials. Med Care Res Rev. 2013;70(6):567-96. Epub 2013/07/31. doi: 10.1177/1077558713496318. PubMed PMID: 23894060.

45. Mosnier-Pudar H, Hochberg G, Eschwege E, Halimi S, Virally ML, Guillausseau PJ, et al. How patients' attitudes and opinions influence self-care behaviours in type 2 diabetes. Insights from the French DIABASIS Survey. Diabetes Metab. 2010;36(6 Pt 1):476-83. Epub 2010/10/16. doi:

10.1016/j.diabet.2010.08.004. PubMed PMID: 20947405. 
46. Abu Hassan H, Tohid H, Mohd Amin R, Long Bidin MB, Muthupalaniappen L, Omar K. Factors influencing insulin acceptance among type 2 diabetes mellitus patients in a primary care clinic: a qualitative exploration. BMC family practice. 2013;14:164. doi: http://dx.doi.org/10.1186/1471-2296-14-164.

47. Rose S, Paul C, Boyes A, Kelly B, Roach D. Stigma-related experiences in non-communicable respiratory diseases: A systematic review. Chron Respir Dis. 2017;14(3):199-216. Epub 2017/01/24. doi:

10.1177/1479972316680847. PubMed PMID: 28111991; PubMed Central PMCID: PMCPMC5720230.

48. Schroedl CJ, Yount SE, Szmuilowicz E, Hutchison PJ, Rosenberg SR, Kalhan R. A qualitative study of unmet healthcare needs in chronic obstructive pulmonary disease. A potential role for specialist palliative care? Ann Am Thorac Soc. 2014;11(9):1433-8. Epub 2014/10/11. doi: 10.1513/AnnalsATS.201404-155BC. PubMed PMID: 25302521; PubMed Central PMCID: PMCPMC4298987.

49. Berger BE, Kapella MC, Larson JL. The experience of stigma in chronic obstructive pulmonary disease. Western journal of nursing research. 2011;33(7):916-32. Epub 2010/10/12. doi:

10.1177/0193945910384602. PubMed PMID: 20940446.

50. BREATHE lung association. BI. STIGMA REPORT. 2018. https://www.lung.ca/sites/default/files/StigmaReportSeptemberFINAL.pdf

\section{Figures}




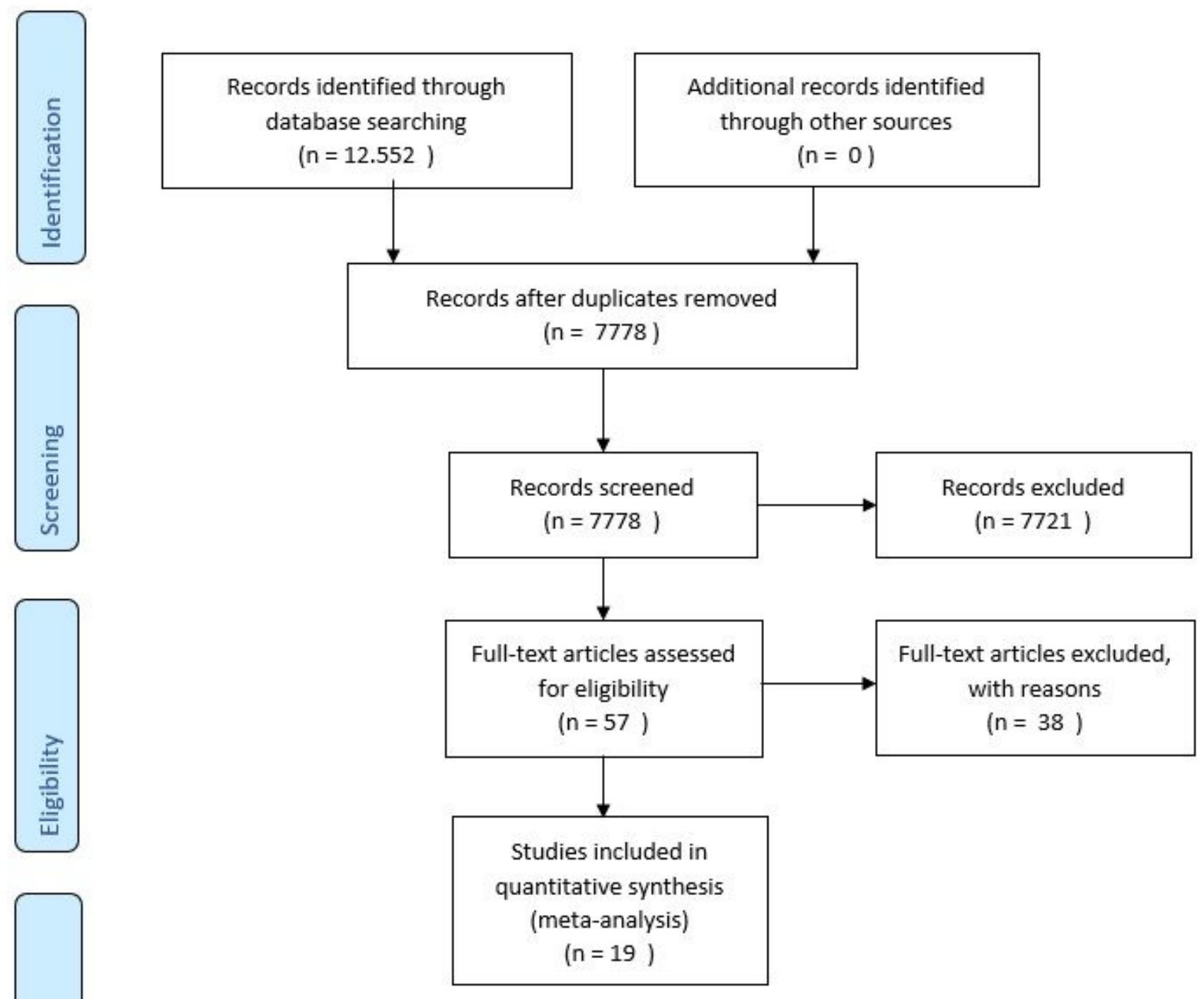

Figure 1

Prisma Flow Chart

\section{Supplementary Files}

This is a list of supplementary files associated with this preprint. Click to download.

- Supplementary.docx 